\title{
TEORI BANK SYARIAH
}

\author{
Hamdi Agustin \\ Univeritas Islam Riau (UIR), Pekanbaru, Indonesia \\ hamdiagustin@eco.uir.ac.id \\ https://doi.org/10.46367/jps.v2i1.279
}

Received: Jan 29, 2021 Revised: Mar 22, 2021 Accepted: Mar 30, 2021 Published: Apr 09, 2021

\begin{abstract}
The purpose of this research is to re-conceptualize the theory of Islamic banking according to the Al-Quran and Hadith. This research needs to be carried out considering that the operational activities of Islamic banks, especially in Indonesia, have been heavily criticized by academic researchers because there have been several deviations from Islamic banking activities that are not in accordance with the provisions of Islamic law. The method used in this research is the method of documentation and reviewing secondary data in the form of theories regarding Islamic banking. The analysis technique used is descriptive. Where the development of Islamic banking literature will be explained in a complete and structured manner so that it will produce an in-depth explanation. The results showed that the theory of Islamic banking is shaped like a building where the foundation of Islamic banking is faith-based on the Al-Quran and Hadith and carries out the characteristics of the Prophet Sallallaahu 'Alaihi Wasallam. After the foundation is in place, it can run the rules of Islamic banking based on sharia which consists of prohibition of all usury practices, prohibition of financing maysir and gharar businesses, financing of real assets, sharing of profits and risk of loss. If sharia has been implemented in sharia banking, a pure sharia bank will be realized so that it will get the blessing of Allah Ta'ala.
\end{abstract}

Keywords: Islamic Bank, Al-Quran, Hadith, Maysir, Gharar.

\begin{abstract}
ABSTRAK
Tujuan penelitian ini adalah untuk membuat kembali konsep teori bank syariah yang sesuai dengan Al-Quran dan Hadits. Penelitian ini pelu dilakukan mengingat bahwa kegiatan operasional bank syariah, terutama di Indonesia telah banyak mendapat kritikan oleh para peneliti akedemisi karena terjadi beberapa penyimpangan kegiatan perbankan syariah yang tidak sesuai dengan ketentuan syariat Islam. Metode yang digunakan dalam penelitian ini adalah metode dokumentasi dan mengkaji data sekunder yang berupa teori-teori mengenai perbankan syariah. Teknik analisis yang digunakan adalah deskriptif. Dimana pengembangan literatur perbankan syariah akan dijelaskan secara lengkap dan terstruktur sehingga akan menghasilkan penjelasan secara mendalam. Hasil penelitian menunjukkan bahwa teori bank syariah berbentuk seperti bangunan dimana fondasi dari bank syariah adalah akidah berdasarkan Al-Quran dan Hadits serta menjalankan sifat Rasulullah Shallallahu 'Alaihi Wasallam. Setelah fondasi sudah ada maka dapat menjalankan aturan bank syariah berdasarkan pada syariat
\end{abstract}


yang terdri dari: larangan segala praktek riba, larangan pembiayaan usaha maysir dan gharar, Pembiayaan pada real asset, berbagi keuntungan dan resiko rugi. Apabila syariat sudah dijalankan pada perbankan syariah maka akan terwujud bank syariah yang murni syariah sehingga mendapat ridho Allah Ta'ala.

Kata Kunci: Bank Syariah, Al-Quran, Hadits, Maysir, Gharar.

\section{PENDAHULUAN}

Bank syariah secara umum dapat diartikan lembaga keuangan yang usaha pokoknya memberikan layanan penyimpanan, pembiayaan dan jasa lalu lintas pembayaran. Bank syariah merupakan bank yang beroperasi sesuai dengan prinsip-prinsip syariah Islam, mengacu kepada ketentuan yang ada dalam AlQuran dan Hadits. Dengan demikian perbankan syariah harus dapat menghindari kegiatan-kegiatan yang mengandung unsur riba dan segala hal yang bertentangan dengan syariah Islam. Adapun perbedaan pokok antara bank syariah dengan bank konvensional terdiri dari beberapa hal. Perbedaan utama adalah bank syariah tidak melaksanakan sistm bunga dalam seluruh aktivitasnya, sedangkan bank konvensional mengunakan sistem bunga. Hal ini memiliki implikasi yang sangat dalam dan berpengaruh pada aspek operasional dan produk yang dikembangkan oleh bank syariah.

Dalam keuangan Islam, bunga uang secara fiqh dikategorikan sebagai riba yang berarti haram. Di sejumlah negara Islam dan berpenduduk mayoritas muslim mulai timbul usaha-usaha untuk mendirikan lembaga bank alternatif non-ribawi. Melihat gagasannya yang ingin membebaskan diri dari mekanisme bunga, pembentukan bank Islam mula-mula banyak menimbulkan keraguan. Hal tersebut muncul karena anggapan bahwa sistem perbankan bebas bunga adalah sesuatu yang mustahil dan tidak lazim, sehingga timbul pula pertanyaan tentang bagaimana nantinya bank Islam tersebut akan membiayai operasinya.

Jumhur (mayoritas/kebanyakan) ulama' sepakat bahwa bunga bank adalah riba, oleh karena itulah hukumnya haram (Kusnan and Hakim 2018). Pertemuan 150 ulama' terkemuka dalam konferensi penelitian Islam di bulan Muharram 1385 H, atau Mei 1965 di Kairo, Mesir menyepakati secara aklamasi bahwa segala keuntungan atas berbagai macam pinjaman semua merupakan praktek riba yang diharamkan termasuk bunga bank. Berbagai forum ulama internasional yang juga mengeluarkan fatwa pengharaman bunga bank.

Abu Zahrah, Abu 'Ala Al-Maududi Abdullah Al-'Arabi dan Yusuf Qardhawi mengatakan bahwa bunga bank itu termasuk riba nasiah yang dilarang oleh Islam (Kusnan and Hakim 2018). Karena itu umat Islam tidak boleh bermuamalah dengan bank yang memakai sistem bunga, kecuali dalam keadaan darurat atau terpaksa. Bahkan menurut Yusuf Qardhawi tidak mengenal istilah darurat atau terpaksa, tetapi secara mutlak beliau mengharamkannya. Pendapat ini dikuatkan oleh Al-Syirbashi, menurutnya bahwa bunga bank yang diperoleh seseorang yang menyimpan uang di bank termasuk jenis riba, baik sedikit maupun banyak. Namun yang terpaksa, maka agama itu membolehkan meminjam uang di bank itu dengan bunga.

Literatur tentang perbankan syariah terbagi dalam dimensi teoritis dan empiris. Karya paling awal yang berhubungan dengan potensi perbankan Islam 
termasuk (Mannan 1968; Ahmad 1987; Saeed 1996; Iqbal and Mirakhor 1999). Para penulis ini membahas berbagai masalah kelembagaan termasuk konsep dan prinsip yang dapat ditafsirkan. Beberapa penelitian sebelumnya meneliti kinerja Bank Islam dan membandingkannya dengan kinerja bank konvensional (Samad 1999; Samad and Hassan 2006; Iqbal 2001; Rosly and Bakar 2003; Samad 2004; Kader et al. 2007; Widagdo and Ika; 2008; Beck et al. 2010; Jaffar and Manarvi 2011; Ansari and Rehman 2011; Wahidudin et al. 2012; Merchant 2012; Zeitun 2012; Babatunde and Olaitan 2013).

Konsep teoritis kajian bank syariah pertama kali pada tahun 1940-an, dimana menerapkan gagasan perbankan yang kegiatan operasionalnya berdasarkan bagi hasil. Konsep teoritis kajian bank syariah ini dilakukan oleh para pemikir Islam seperti Anwar Qureshi (1946), Naiem Siddiqi (1948) dan Mahmud Ahmad (1952) (El-Galfy and Khiyar 2012). Selanjutnya pembahasan yang lebih terperinci dan lengkap mengenai gagasan perbankan syariah ditulis oleh dua ulama besar Pakistan yaitu Abul A'la Al-Maududi (1961) dan Muhammad Hamidullah (1944-1962). Penelitian ini sangat penting dilakukan untuk konsistensi bank yang sesuai dengan syariah berdasarkan Al-Quran dan Hadits. Sehingga dapat ditemukan hal yang mesti selalu dijaga dalam kegiatan bank syariah.

Tujuan penelitian ini adalah untuk membuat kembali konsep teori bank syariah yang sesuai dengan Al-Quran dan Hadits. Walaupun hasil penelitian (Erol and El-Bdour 1989; Gerald and Cuningham 1997; Naser et al. 1999) menunjukkan bahwa tauhid bukan merupakan faktor utama pelanggan bergabung ke bank syariah. Sementara operasional bank syariah harus berdasarkan pada syariah Islam dengan tauhid yang benar. Penelitian ini pelu dilakukan mengingat bahwa kegiatan operasional bank syariah, terutama di Indonesia telah banyak mendapat kritikan oleh para peneliti akedemisi karena terjadi beberapa penyimpangan kegiatan perbankan syariah yang tidak sesuai dengan ketentuan syariah Islam. Salah satu contohnya adalah transaksi akad pembiayaan murabahah dimana dalam prakteknya masih terjadi pemberian dana oleh bank kepada nasabah yang semestinya dalam ketentuan syariah bank menyerahkan barang yang dipesan oleh nasabah.

\section{TELAAH LITERATUR}

Perbankan adalah satu lembaga yang melaksanakan tiga fungsi utama, yaitu menerima simpanan uang, meminjamkan uang, dan memberikan jasa pengiriman uang. Didalam sejarah perekonomian kaum muslimin, sistem perbankan telah ada sejak zaman Rasulullah Shallallahu 'Alaihi Wasallam dimana dalam sejarah perekonomian umat Islam, pembiayaan yang dilakukan dengan akad yang sesuai syariah telah menjadi bagian dari tradisi umat Islam sejak zaman Rasulullah Shallallahu 'Alaihi Wasallam. Praktek-praktek seperti menerima titipan harta, meminjamkan uang untuk keperluan konsumsi dan untuk keperluan bisnis, serta melakukan pengiriman uang, telah lazim dilakukan sejak zaman Rasulullah Shallallahu 'Alaihi Wasallam.

Dengan demikian, fungsi utama perbankan modern yaitu menerima deposit, menyalurkan dana, dan melakukan transfer dana sudah ada dalam kegiatan perekonomian di zaman Rasulullah Shallallahu 'Alaihi Wasallam. 
Masyarakat Makkah selalu menyimpan harta kepada Rasulullah Shallallahu 'Alaihi Wasallam karena beliau dikenal dengan julukan Al-Amin, dipercaya, sehingga pada saat terakhir sebelum Rasul hijrah ke Madinah, beliau meminta Sayidina Ali R.A. untuk mengembalikan semua titipan itu kepada yang memilikinya. Dalam konsep ini, yang dititipi tidak dapat memanfaatkan harta titipan tersebut (Kusnan and Hakim 2018).

Seorang sahabat Rasulullah Shallallahu 'Alaihi Wasallam, Zubair bin Awwam R.A. memilih tidak menerima titipan harta. Ia lebih suka menerimanya dalam bentuk pinjaman. Tindakan Zubir menimbulkan implikasi yang berbeda, yakni pertama, dengan mengambil uang itu sebagai pinjaman, ia mempunyai hak untuk memanfaatkannya; kedua, karena bentuknya pinjaman, ia berkewajiban untuk mengembalikannya secara utuh. Sahabat lain, Ibnu Abbas tercatat melakukan pengiriman uang ke Kufah. Juga tercatat Abdullah bin Zubair di Makkah juga melakukan pengiriman uang ke adiknya Mus'ab bin Zubair yang tinggal di Irak (Muhith 2102; Kusnan and Hakim 2018).

Di zaman Rasullah Shallallahu 'Alaihi Wasallam. Juga terdapat lembaga keuangan dan juga lembaga yang mengurusi kepentingan masyarakat, yaitu baitul maal. Baitul mal merupakan lembaga keuangan pertama yang ada pada zaman Rasulullah Shallallahu 'Alaihi Wasallam. Lembaga ini pertama kali hanya berfungsi untuk menyimpan harta kekayaan negara dari zakat, infak, sedekah, pajak dan harta rampasan perang. Baitul mal merupakan acuan dari perbankan syariah yang berfungsi sebagai tempat simpanan harta dan penyaluran harta.

Berikut ini disajikan pada Tabel 1 perkembangan praktik konsep perbankan syariah di zaman Nabi Muhammad Shallallahu 'Alaihi Wasallam dan kekalifahan.

\section{Tabel 1. Perkembangan Praktik Konsep Perbankan Syariah Di Zaman Nabi Muhammad SAW Dan Kekalifahan}

\begin{tabular}{|c|c|c|c|c|c|}
\hline \multirow[t]{2}{*}{ Zaman } & \multirow[t]{2}{*}{ Keterangan } & \multicolumn{4}{|c|}{$\begin{array}{c}\text { Konsep Bank Yang } \\
\text { Dilakukan }\end{array}$} \\
\hline & & $\mathbf{M}$ & P1 & $\mathbf{T}$ & P2 \\
\hline $\begin{array}{l}\text { Nabi } \\
\text { Muhammad } \\
\text { SAW. } \\
1-11 \mathrm{H} / \\
622-632 \mathrm{M}\end{array}$ & $\begin{array}{l}\text { Nabi Muhammad SAW yang dikenal dengan } \\
\text { julukan Al-Amin, dipercaya oleh masyarakat } \\
\text { Makkah menerima simpanan harta, sehingga } \\
\text { pada saat terakhir sebelum Rasul hijrah ke } \\
\text { Madinah, beliau meminta Sayidina Ali RA. } \\
\text { untuk mengembalikan semua titipan itu } \\
\text { kepada yang memilikinya. Dalam konsep ini, } \\
\text { yang dititipi tidak dapat memanfaatkan harta } \\
\text { titipan tersebut. }\end{array}$ & & $\sqrt{ }$ & $\sqrt{ }$ & $\sqrt{ }$ \\
\hline $\begin{array}{l}\text { Zubair bin } \\
\text { Al-Awwam }\end{array}$ & $\begin{array}{l}\text { Memilih tidak menerima titipan harta. Beliau } \\
\text { lebih suka menerimanya dalam bentuk } \\
\text { pinjaman. Tindakan ini menimbulkan } \\
\text { implikasi yang berbeda: pertama, dengan } \\
\text { mengambil uang itu sebagai pinjaman, beliau } \\
\text { mempunyai hak untuk memanfaatkannya; } \\
\text { kedua, karena bentuknya pinjaman, maka ia } \\
\text { berkewajiban mengembalikannya utuh }\end{array}$ & & & & \\
\hline Ibnu Abbas & $\begin{array}{l}\text { Ibnu Abbas tercatat melakukan pengiriman } \\
\text { uang ke Kufah }\end{array}$ & & & $\sqrt{ }$ & \\
\hline
\end{tabular}




\begin{tabular}{|c|c|c|c|c|c|}
\hline $\begin{array}{l}\text { Abdullah bin } \\
\text { Zubair }\end{array}$ & $\begin{array}{l}\text { Abdullah bin Zubair di Makkah juga } \\
\text { melakukan pengiriman uang ke adiknya } \\
\text { Misab bin Zubair yang tinggal di Irak. }\end{array}$ & & & $\sqrt{ }$ & \\
\hline $\begin{array}{l}\text { Masa } \\
\text { Khalifah } \\
\text { Abu Bakar } \\
\text { Ash Shiddiq } \\
11-13 \mathrm{H} / \\
632-634 \mathrm{M}\end{array}$ & $\begin{array}{l}\text { Abu Bakar merintis berdirinya baitul mal } \\
\text { dalam arti yang lebih luas. Baitul mal } \\
\text { merupakan lembaga yang dapat dijadikan } \\
\text { sebagai bentuk opersional bank syariah. } \\
\text { kegiatan baitul mal menyimpan dan } \\
\text { menyalurkan harta negara. }\end{array}$ & $\sqrt{ }$ & & & $\sqrt{ }$ \\
\hline $\begin{array}{l}\text { Masa } \\
\text { Khalifah } \\
\text { Umar bin } \\
\text { Khatab } \\
13-23 \mathrm{H} / \\
634-644 \mathrm{M}\end{array}$ & $\begin{array}{l}\text { Umar membangun sebuah rumah khusus } \\
\text { untuk menyimpan harta, membentuk diwan- } \\
\text { diwannya (kantor-kantornya), mengangkat } \\
\text { para penulisnya, menggunakan cek untuk } \\
\text { membayar tunjangan menetapkan gaji-gaji } \\
\text { dari harta baitul mal. Dalam perdagangan } \\
\text { antara negeri syam dengan yaman telah } \\
\text { menggunakan cek. Pemberian modal untuk } \\
\text { modal kerja berbasis bagi hasil, seperti } \\
\text { mudharabah, musyarakah, muzara'ah, } \\
\text { musaqah, telah dikenal sejak awal di antara } \\
\text { kaum Muhajirin dan kaum Anshar. }\end{array}$ & & $\sqrt{ }$ & $\sqrt{ }$ & $\sqrt{ }$ \\
\hline $\begin{array}{l}\text { Masa } \\
\text { Khalifah } \\
\text { Utsman bin } \\
\text { Affan } \\
\text { 23-35 H / } \\
644-656 \mathrm{M}\end{array}$ & $\begin{array}{l}\text { Melanjutkan kegiatan baitul mal dari masa } \\
\text { khalifar Umar bin Khatab baik dalam } \\
\text { pemasukan, pengeluaran, pengorganisasian } \\
\text { dan sebagainya. }\end{array}$ & & $\sqrt{ }$ & $\sqrt{ }$ & $\sqrt{ }$ \\
\hline $\begin{array}{l}\text { Masa } \\
\text { Khalifah Ali } \\
\text { bin Abi } \\
\text { Thalib } \\
35-40 \mathrm{H} / \\
656-661 \mathrm{M}\end{array}$ & $\begin{array}{l}\text { Pada masa pemerintahan Ali bin Abi Talib, } \\
\text { kondisi baitul mal ditempatkan kembali pada } \\
\text { posisi yang sebelumnya. menyimpan dan } \\
\text { menyalurkan kekayaan Negara. }\end{array}$ & $\sqrt{ }$ & & & $\sqrt{ }$ \\
\hline $\begin{array}{l}\text { Bani } \\
\text { Abbasiyah } \\
132-656 \mathrm{H} / \\
750-1258 \mathrm{M}\end{array}$ & $\begin{array}{l}\text { 1. Sudah mulai muncul kegiatan banker } \\
\text { berupa tiga aspek, yakni menerima } \\
\text { tabungan/deposit, melakukan kegiatan } \\
\text { pembiayaan/pinjaman, dan kegiatan } \\
\text { pengiriman uang. } \\
\text { 2. Mulai beredarnya saq (cek) secara luas } \\
\text { untuk sarana melakukan pembayaran } \\
\text { transaksi perdagangan. }\end{array}$ & & & $\sqrt{ }$ & \\
\hline
\end{tabular}

Hasil penelitian yang dilakukan oleh (Erol and El-Bdour 1989) di Malaysia, menemukan alasan tauhid bukan merupakan alasan utama bagi pelanggan muslim untuk bergabung dengan bank syariah. Penelitian ini berbeda dengan hasil penelitian yang dilakukan oleh (Gerald and Cuningham 1997) yang dilakukan di Singapura, penelitian ini menemukan bukti bahwa alasan tauhid ternyata bukan menjadi pertimbangan utama muslim Singapura untuk bermitra dengan bank syariah. Hal ini dapat dilihat dari tingkat presentase jawaban responden hanya $32 \%$ saja. Namun ketika faktor tauhid dikombinasikan dengan 
alasan-alasan ekonomis lainnya seperti tingkat profit yang akan di dapat maka jawaban responden meningkat tajam menjadi $72 \%$.

Sementara itu hasil penelitian yang dilakukan oleh (Naser et al. 1999) yang dilakukan di Jordania juga menemukan bukti bahwa faktor tauhid semata bukan merupakan pendorong utama untuk bermitra dengan bank syariah. Penelitian (Saiti 2015) menemukan bahwa dalam hal sikap terhadap bank syariah, terdapat banyak perbedaan sikap antara muslim dan non muslim di negara yang mayoritas muslim. Dalam konteks kriteria pemilihan bank, terdapat empat perbedaan yang signifikan antara Muslim dan non-Muslim yaitu, iklan media massa, kredit dengan persyaratan yang menguntungkan, konseling keuangan dan lokasi yang dekat dengan tempat bekerja, sedangkan 18 kriteria lainnya tidak menunjukkan perbedaan yang signifikan.

\section{METODE PENELITIAN}

Jenis data yang digunakan adalah data kualitatif dan sumber data yang digunakan dalam penelitian ini adalah data sekunder, yang diperoleh dari literatur kepustakaan dengan cara mempelajari, memahami, mencermati, menelaah, dan mengidentifikasikan hal-hal yang sudah ada dan apa yang belum ada dalam bentuk artikel jurnal atau karya-karya ilmiah yang berkaitan dengan topik penelitian. Teknik analisis data dalam penelitian ini adalah analisis deskriptif.

\section{HASIL DAN PEMBAHASAN PENELITIAN}

\section{Gambar 1 Teori Bank Syariah}

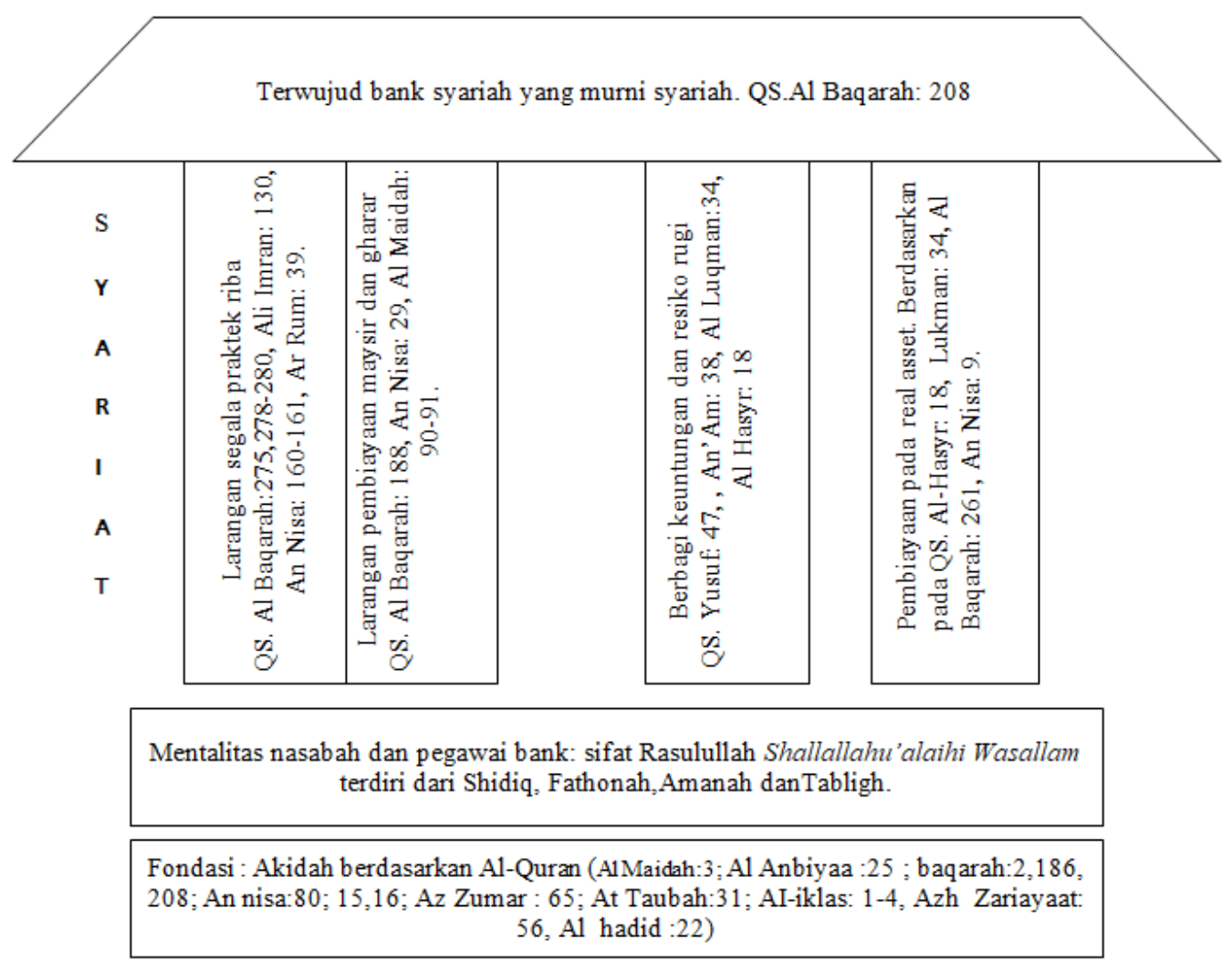


Bank syariah adalah segala kegiatan perbankan berdasarkan Al-Quran dan Hadits. Kegiatan bank syariah berdasakan syariat Islam dapat dilakukan dengan benar apabila mempunyai fondasi berupa akidah yang benar. Hal ini terlihat pada Gambar 1, yang menunjukkan bahwa bank syariah berbentuk seperti bangunan dimana fondasi dari bank syariah adalah akidah berdasarkan Al-Quran dan Hadits serta menjalankan sifat Rasulullah Shallallahu 'Alaihi Wasallam. Setelah fondasi sudah ada maka dapat menjalankan aturan bank syariah berdasarkan pada syariat yang terdri dari: (1) Larangan segala praktek riba. berdasarkan pada QS. Al Baqarah: 278-280, Ali Imran: 130, An Nisa: 160-161, Ar Rum: 39. (2) Larangan pembiayaan usaha maysir dan gharar. Berdasarkan pada QS. Al Baqarah: 188, An Nisa: 29, Al Maidah: 90-91. (3) Pembiayaan pada real asset. Berdasarkan pada QS. Al-Hasyr: 18, Lukman: 34, Al Baqarah: 261, An Nisa: 9. (4) Berbagi keuntungan dan resiko rugi (profit and loss). Berdasakan pada QS. Yusuf: 47, Al Lukman: 34, Al An'am: 38, Al Hasyr: 18. Apabila syariat sudah dijalankan pada perbankan syariah maka akan terwujud bank syariah yang murni syariah sehingga mendapat ridho Allah Ta'ala sesuai dengan QS. Al Baqarah ayat 208.

\section{Akidah}

Secara bahasa akidah berasal dari kata $a l$-'aqdu, artinya: mengikat, memutuskan, menguatkan, mengokohkan, keyakinan, dan kepastian. Adapun secara istilah, akidah memiliki makna umum dan khusus. [At-Talâzum bainal 'Akidah wasy Syari'ah, halaman 9, karya syaikh Dr. Nashir bin Abdul Karim al'Aql] (Atsari 2018). Akidah lebih luas daripada tauhid. Syaikh Abdul Aziz bin Baz menjelaskan bahwa akidah itu mencakup tauhid, jadi akidah lebih luas. "Akidah adalah apa yang menjadi keyakinan kuat seseorang di hatinya dan ia beranggapan dengan akidah itu ia beragama dan menyembah Allah. Termasuk di dalam cakupan akidah adalah tauhid kepada Allah dan beriman bahwa Allah Maha Pencipta, Maha Pemberi Rezeki dan Allah memiliki asmaul husna dan sifat yang tinggi" [Majmu' Fatawa syaikh Bin Baz 6/277] (Bahraen 2019).

Makna akidah secara umum adalah: keyakinan kuat yang tidak ada keraguan bagi orang yang meyakininya, baik keyakinan itu haq atau batil. Sedangkan akidah dengan makna khusus adalah akidah Islam, yaitu: pokok-pokok agama dan hukum-hukum yang pasti, yang berupa keimanan kepada Allah Ta'ala, malaikat-malaikat-Nya, kitab-kitab-Nya, para nabi-Nya, hari akhir, serta beriman kepada takdir yang baik dan yang buruk. Dan perkara lainnya yang diberitakan oleh Allah Ta'ala dalam Al-Quran dan oleh Rasul-Nya di dalam Hadits-Hadits yang shahih. Termasuk akidah Islam adalah kewajiban-kewajiban agama dan hukum-hukumnya yang pasti. Semuanya itu wajib diyakini dengan tanpa keraguan firman Allah Ta'ala berkenaan dengan akidah sebagai berikut:

QS. Azh-Zariayaat (51) ayat 56:

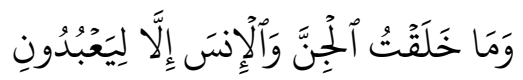

Artinya: "Dan Aku tidak menciptakan jin dan manusia melainkan supaya mereka mengabdi kepada-Ku”.

QS. Al-Anbiyaa' (21) ayat 25:

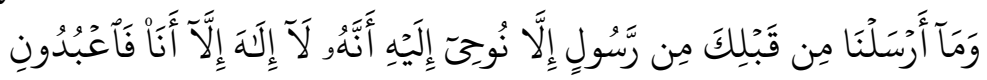


Artinya: "Dan kami tidak mengutus seorang rasulpun sebelum kamu melainkan kami wahyukan kepadanya, bahwasanya tidak ada Tuhan (yang hak) melainkan aku, Maka sembahlah olehmu sekalian akan aku”.

Dari firman Allah Ta'ala di atas dapat diambil Pokok landasan akidah dalam bank syariah secara ringkas adalah sebagai berikut: (1) Yakin dan berharap hanya kepada Allah Ta'ala. (2) Semua permasalahan dan kejadian dalam perbankan syaiah atas kehendak Allah Ta'ala. (3) Membatasi sumber rujukan dalam masalah bank syariah hanya berdasarkan pada Al-Quran dan Sunnah Rasulullah Shallallahu 'Alaihi Wasallam. (4) Merujuk pada Hadits-Hadits shahih dalam masalah-masalah perbankan syariah, baik Hadits-Hadits tersebut mutawatir maupun ahad. (5) Tidak menggunakan akal fikiran yang di dorong dari nafsu dan keinginan dunia sehingga mengartikan bank berdasarkan syariah sesuai dengan keinginan mereka. (6) Menolak ajaran dan pemikiran ekonomi selain ekonomi berlandaskan Al-Quran dan sunnah Rasulullah Shallallahu 'Alaihi Wasallam.

Imam Al Barbahari rahimahullah berkata: "Ketahuilah saudaraku, semoga Allah merahmatimu, bahwa agama Islam itu datang dari Allah Tabaaraka Wa Ta'ala. Tidak disandarkan pada akal atau pendapat-pendapat seseorang. Janganlah engkau mengikuti sesuatu hanya karena hawa nafsumu. Sehingga akibatnya agamamu terkikis dan akhirnya keluar dari Islam. Engkau tidak memiliki hujjah. Karena Rasulullah Shallallahu 'Alaihi Wasallam telah menjelaskan As Sunnah kepada ummatnya, dan juga kepada para sahabatnya. Merekalah (para sahabat) As Sawaadul A'zham. Dan AsSawaadul A'zham itu adalah al haq dan ahlul haq".

Beliau juga berkata: "Umar bin Al Khattab Radhiallahu'anhu berkata: Tidak ada toleransi bagi seseorang untuk melakukan kesesatan, karena petunjuk telah cukup baginya. Tidaklah seseorang meninggalkan petunjuk agama, kecuali baginya kesesatan. Perkara-perkara agama telah dijelaskan, hujjah sudah ditetapkan, tidak ada lagi toleransi. Karena As Sunnah dan Al Jama'ah telah menetapkan hukum agama seluruhnya serta telah menjelaskannya kepada manusia. Maka bagi manusia hendaknya mengikuti petunjuk mereka”.

\section{Mentalitas Nasabah Dan Pegawai Bank: Sifat Rasulullah Shallallahu 'Alaihi Wasallam}

Shidiq

Prilaku shidiq yang dipraktekkan Rasulullah Shallallahu 'Alaihi Wasallam sesuai dengan firman Allah Ta'ala dalam QS. An-Najm (53) ayat 4-5:

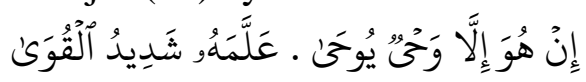

Artinya: "Ucapannya itu tiada lain hanyalah wahyu yang diwahyukan (kepadanya). Yang diajarkan kepadanya oleh (Jibril) yang sangat kuat”.

Pegawai bank syariah dan nasabah haruslah memiliki sifat shidiq atau jujur. Jujur adalah kesamaan antara berita yang disampaikan dengan fakta atau fenomena yang ada, sesuai dengan yang dipraktikkan Rasulullah Shallallahu 'Alaihi Wasallam. Dalam prilaku pegawai bank, sifat jujur tercermin pada kejujuran dalam membuat laporan keuangan perusahaan, jujur dalam perhitungan yang berhubungan tabungan dan pembiayaan nasabah serta segala perhitungan yang berhubungan dengan keuangan perusahaan. Sementara perilaku nasabah 
yang menerima pembiayaan harus jujur dalam membayar ansuran pinjaman yang diterimanya.

\section{Fathanah}

Prilaku fathanah yang dipraktikkan Rasulullah Shallallahu 'Alaihi Wasallam. Fathanah pada umumnya diartikan sebagai kecerdasan, kemahiran atau penguasaan terhadap bidang tertentu. Fathanah merujuk pada dimensi mental yang sangat mendasar dan menyeluruh sehingga dapat diartikan bahwa fathanah merupakan kecerdasan yang mencakup kecerdasan intelektual, emosional dan terutama spiritual. Pegawai bank yang memiliki sikap fathanah tidak saja menguasai opeasional bank berdasarkan syariah yang benar, tetapi memiliki keteguhan hati yang kuat. Keputusan-keputusannya menunjukkan seorang profesional yang didasarkan sikap akhlak seperti akhlak Rasulullah Shallallahu 'Alaihi Wasallam. Seorang yang fathanah tidak hanya cerdas, tetapi juga memiliki kebijaksanaan atau kearifan dalam berfikir dan bertindak. Selain itu, sifat fathanah mampu menempatkan dirinya sebagai fokus perhatian lalu menjadikan dirinya sebagai figur teladan karena keahlian dan kepribadiannya yang mampu menumbuhkan situasi yang menentramkan. Makna fathanah pada perbankan syariah meliputi dua aktivitas terdiri dari: pertama, fathanah dalam hal memperoleh modal bank yang berkaitan dengan aktivitas cara mendapatkan dana yang sesuai dengan akad-akad syariah Islam. kedua, fathanah aktivitas pembiayaan yang untuk usaha yang halal seperti tidak ada unsur riba, maysir dan gharar.

\section{Amanah}

Pegawai bank dan nasabah hendaknya mengikuti prilaku amanah yang dipraktekkan Rasulullah Shallallahu 'Alaihi Wasallam. Dengan demikian mereka akan selalu bertanggungjawab atas segala yang dia lakukan dalam hal muamalahnya. Bertanggungjawab dengan selalu menjaga hak dan kewajiban dalam bermuamalah pada bank syariah.

\section{Tabligh}

Karakteristik pedagang yang baik dalam Islam yang terakhir yaitu tabligh. Salah satu peranan dari sikap tabligh yang merupakan salah satu sifat akhlaqul karimah dari Rasulullah Shallallahu 'Alaihi Wasallam yaitu menyampaikan kebenaran melalui suri teladan dan perasaan cinta yang mendalam. Kemampuan berkomunikasi dalam kata tabligh menunjukkan proses menyampaikan sesuatu untuk mempengaruhi orang lain melalui perkataan yang baik. Dalam prakteknya, pegawai bank syariah memberikan informasi yang benar terhadap produk bank syaiah, sehingga nasabah mendapatkan kepuasan dan memahami bahwa produk bank syaiah berbeda dengan produk bank konvensional.

\section{Syariat}

Syariat menurut istilah agama adalah: apa yang Allah Ta'ala syariatkan (buat peraturan) yang berupa agama, bentuk jama'nya adalah syarâi'. Kami telah menjadikan kamu wahai Muhammad berada di atas suatu jalan yang jelas dari urusan (agama itu) yang akan menghantarkanmu menuju al-haq. "Maka ikutilah 
syariat itu", yaitu maka amalkanlah hukum-hukumnya pada umatmu. "Dan janganlah kamu ikuti hawa nafsu orang-orang yang tidak mengetahui", terhadap tauhidulloh dan syari'a-syari'atNya untuk hamba-hambaNya, mereka adalah orang-orang kafir Quroisy dan yang menyetujui mereka" [dalam Tafsir Fathul Qadir juz: 5 hlm: 11] (Atsari 2018).

Dari keterangan ini, jelaslah bahwa istilah syariat pada ayat-ayat ini mencakup semua bagian agama yang dibawa oleh Rasulullah Shallallahu 'Alaihi Wasallam, yang berupa al-haq (kebenaran) dan al-huda (petunjuk), dalam masalah akidah dan hukum-hukum. Sedangkan makna syariat secara khusus adalah: peraturan yang Allah Ta'ala buat yang berupa hukum-hukum, perintahperintah, dan larangan-larangan. Hal ini seperti firman Allah Ta'ala dalam QS. Al-Maidah (5) ayat 48 yang artinya: Untuk tiap-tiap umat diantara kamu [maksudnya: umat Nabi Muhammad dan umat-umat yang sebelumnya] Kami berikan syari'at (aturan) dan jalan yang terang.

Sebagian orang beranggapan bahwa menegakkan syariat itu kewajiban penguasa, sehingga mereka selalu menuntut penguasa untuk menerapkan hukumhukum Allah Ta'ala, sedangkan mereka sendiri nampak jauh dari tuntunan syariat. Ini adalah pemahaman yang keliru. Karena sesungguhnya kewajiban menegakkan hukum Allah Ta'ala mengenai setiap orang Muslim termasuk mereka yang terlibat dalam perbankan syariah yaitu karyawan bank dan nasabah.

Imam Ibnu Katsir Rahimahullah berkata: "Allah Ta'ala bersumpah dengan diri-Nya yang mulia, yang suci, bahwa seseorang tidak beriman sampai menjadikan Rasulullah Shallallahu 'Alaihi Wasallam sebagai hakim dalam segala perkara. Maka apa yang beliau putuskan adalah haq, yang wajib ditunduki secara lahir dan batin. Oleh karena inilah Allah Ta'ala berfirman yang artinya: "kemudian mereka tidak merasa keberatan dalam hati mereka terhadap putusan yang kamu berikan, dan mereka menerima dengan sepenuhnya". Yaitu jika mereka telah menjadikanmu sebagai hakim, mereka mentaatimu di dalam batin mereka, kemudian mereka tidak merasa keberatan dalam hati mereka terhadap putusan yang kamu berikan, dan mereka tunduk kepadanya lahir batin, dan menerimanya dengan sepenuhnya, tanpa menolak dan membantah" [Tafsir Ibnu Katsir, QS. An-Nisa (4) ayat 65 (Atsari 2018).

Oleh karena itulah Nabi Shallallahu 'Alaihi Wasallam bersabda: "Setiap kamu adalah pemimpin/pengatur dan akan ditanya tentang kepemimpinannya. Maka imam adalah pemimpin/pengatur dan akan ditanya tentang kepemimpinannya. Seorang laki-laki (kepala rumah tangga) adalah pemimpin/pengatur terhadap keluaganya dan akan ditanya tentang kepemimpinannya. Seorang wanita (ibu rumah tangga) adalah pemimpin/pengatur di dalam rumah suaminya dan akan ditanya tentang kepemimpinannya. Seorang pelayan adalah pemimpin/pengatur pada harta tuannya dan akan ditanya tentang kepemimpinannya" [HR. Al-Bukhari, no: 2558, dari Ibnu Umar] (Atsari 2018).

Perkara pokok dalam agama Islam adalah seorang muslim berkewajiban masuk ke dalam agama Islam secara total (kaffah) dengan menjalan semua perintah dan menjauhi semua larangan sesuai dengan kemampuannya. Dengan demikian berkewajiban mengikuti Islam di dalam aspek akidah (keyakinan), ibadah (ketundukan hamba kepada Penciptanya), muamalah (hubungan antar hamba) yang salah satunya pada kegiatan perbankan, sehingga menerapkan 
syariat Islam yang sesuai dengan Al-Quran dan Hadits bukan hanya yang berkaitan dengan ibadah mahdhah (murni), tetapi juga yang berkaitan dengan aspek bank. Bahkan wajib menegakkan hukum Allah Ta'ala dalam seluruh aspek kegiatan operasional bank. Namun yang paling penting adalah aspek akidah, yaitu pemahaman dan peneapan nilai tauhid pada semua karyawan bank syariah.

Hubungan akidah dan syariat terdapat pada perkataan Imam Muhammad bin Nashr al-Marwazi di dalam kitab ash-Shalat: "Perumpamaan iman pada amalan seperti qolbu (hati; jantung) pada badan, keduanya tidak terpisahkan. Tidaklah ada orang yang memiliki badan yang hidup, namun tidak ada qolbunya. Juga tidak ada orang yang memiliki qolbu, namun tanpa badan. Maka keduanya itu adalah dua perkara yang berbeda, namun hukumnya satu, sedangkan maknanya berbeda. Perumpamaan keduanya juga seperti biji yang memiliki luar dan dalam, sedangkan biji itu satu.Tidaklah dikatakan dua, karena sifat keduanya yang berbeda. Maka demikian juga amalan-amalan Islam dari (ajaran) Islam adalah iman sebelah luar, yaitu termasuk amalan-amalan anggota badan. Sedangkan iman adalah Islam sebelam dalam, yaitu termasuk amalan-amalan hati" [Kitabul Iman, hlm: 283, karya Syaikhul Islam Ibnu Taimiyah] (Atsari 2018). Berdasarkan perkataan Imam Muhammad bin Nashr al-Marwazi ini, tindakan seorang muslim memisahkan syariat dengan akidah tidak benar.

\section{Larangan Riba}

Al-Hanafiyyah menyatakan "riba adalah kelebihan yang tidak ada penggantinya (imbalannya) menurut standar syar'i, yang disyaratkan untuk salah satu dari dua orang yang melakukan akad penukaran (harta)". [al-Mausû'ah alFiqhiyyah al-Kuwaitiyyah, 22/50]. Syafi'iyyah menyatakan "riba adalah akad untuk mendapatkan ganti tertentu yang tidak diketahui persamaannya menurut standar syar'i (agama Islam) pada waktu perjanjian, atau dengan menunda penyerahan kedua barang yang ditukar, atau salah satunya". [al-Mausû'ah alFiqhiyyah al-Kuwaitiyyah, 22/50]. Hanabilah menyatakan "riba adalah perbedaan kelebihan di dalam perkara-perkara, mengakhirkan di dalam perkaraperkara, pada perkara-perkara khusus yang yang ada keterangan larangan riba dari syara' (agama Islam), dengan nash (keterangan tegas) di dalam sebagiannya, dan qiyas pada yang lainnya." [al-Mausu'ah al-Fiqhiyyah alKuwaitiyyah, 22/50]. Firman Allah Ta'ala yang berkenaan dengan riba sebagai berikut:

QS. Al Baqarah (2) ayat 275, 278-280:

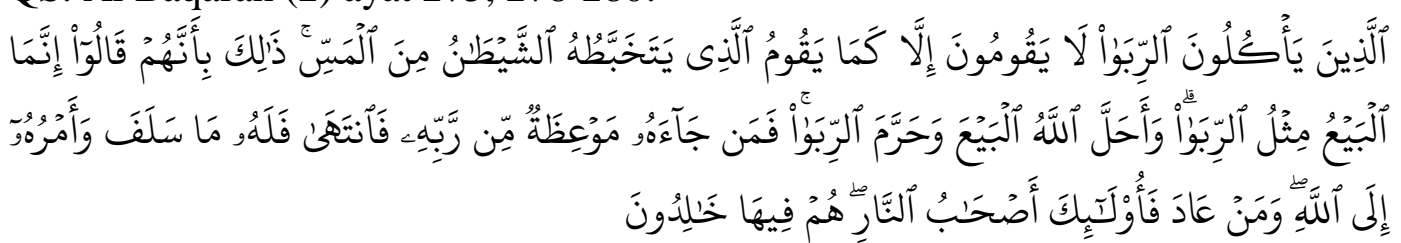

Artinya: "Orang-orang yang makan (mengambil) riba tidak dapat berdiri melainkan seperti berdirinya orang yang kemasukan syaitan lantaran (tekanan) penyakit gila. keadaan mereka yang demikian itu, adalah disebabkan mereka Berkata (berpendapat), Sesungguhnya jual beli itu sama dengan riba, padahal Allah Telah menghalalkan jual beli dan mengharamkan riba. orang-orang yang Telah sampai kepadanya larangan dari Tuhannya, lalu terus berhenti (dari mengambil riba), Maka baginya apa yang Telah diambilnya dahulu (sebelum 
datang larangan); dan urusannya (terserah) kepada Allah. orang yang kembali (mengambil riba), Maka orang itu adalah penghuni-penghuni neraka; mereka kekal di dalamnya".

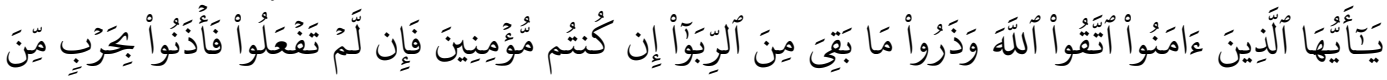

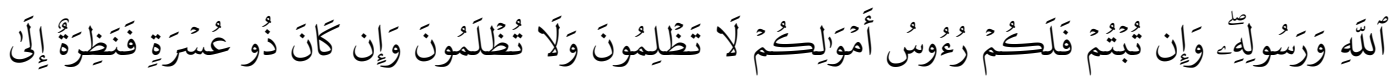

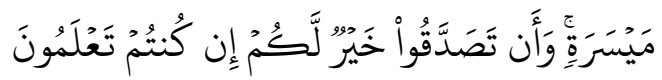

Artinya: "Hai orang-orang yang beriman, bertakwalah kepada Allah dan tinggalkan sisa riba (yang belum dipungut) jika kamu orang-orang yang beriman. Maka jika kamu tidak mengerjakan (meninggalkan sisa riba), Maka Ketahuilah, bahwa Allah dan rasul-Nya akan memerangimu. Dan jika kamu bertaubat (dari pengambilan riba), Maka bagimu pokok hartamu; kamu tidak menganiaya dan tidak (pula) dianiaya. Dan jika (orang yang berhutang itu) dalam kesukaran, Maka berilah tangguh sampai dia berkelapangan. Dan menyedekahkan (sebagian atau semua utang) itu, lebih baik bagimu, jika kamu Mengetahui.

Nabi Muhammad Shallallahu 'Alaihi Wasallam telah melarang umatnya dari kegiatan riba dan memberitakan bahwa riba termasuk salah satu dari tujuh dosa besar. Sebagaimana disebutkan dalam Hadits: "Dari Abu Hurairah Radhiyallahuanhu, dari Nabi Shallallahu 'Alaihi Wasallam, Beliau bersabda: "Jauhilah tujuh (dosa) yang membinasakan!" Mereka (para sahabat) bertanya, "Wahai Rasululah! Apakah itu?” Beliau menjawab, "Syirik kepada Allah, sihir, membunuh jiwa yang Allah haramkan kecuali dengan haq, memakan riba, memakan harta anak yatim, berpaling dar iperang yang berkecamuk, menuduh zina terhadap wanita-wanita merdeka yang menjaga kehormatan, yang beriman, dan yang bersih dar izina" [HR. al-Bukhâri, no. 3456; Muslim, no. 2669].

Imam Nawawi Rahimahullah berkata: "Kaum Muslimin telah sepakat akan haramnya riba. Riba itu termasuk kabâir (dosa-dosa besar). Ada yang mengatakan bahwa riba diharamkan dalam semua syari'at (Nabi-Nabi), di antara yang menyatakannya adalah al-Mawardi" [al-Majmû' Syarhul Muhadzdzab, 9/391]. Syaikhul Islam oleh Ibnu Taimiyah Rahimahullah berkata: "Melakukan riba hukumnya haram berdasarkan Al-Qurân, as-Sunnah, dan ijma "' [Majmû' alFatâwâ, 29/391].

\section{Larangan Gharar dan Maysir}

Menurut bahasa Arab, makna al-gharar adalah "al-khathr (pertaruhan)". Syaikhul Islam Ibnu Taimiyyah menyatakan: "al-gharar adalah yang tidak jelas hasilnya (majhul al- 'aqibah)”. Sedangkan menurut Syaikh As-Sa'di "al-gharar adalah al-mukhatharah (pertaruhan) dan al-jahalah (ketidakjelasan)". Perihal ini masuk dalam kategori perjudian. Sehingga dari penjelasan ini dapat digabung bahwa jual beli gharar adalah semua jual beli yang mengandung ketidakjelasan, pertaruhan dan perjudian. Sesuai dengan QS. Al Maidah (5) ayat 91, diantara hikmah larangan jual beli ini adalah adanya pertaruhan dan menimbulkan sikap permusuhan pada orang yang dirugikan. Larangan ini juga mengandung maksud untuk menjaga harta agar tidak hilang dan menghilangkan sikap permusuhan yang terjadi pada orang akibat jenis jual beli ini.

Mengenal kaidah gharar dalam transaksi jual beli sangatlah penting, karena banyak permasalahan jual-beli yang bersumber dari ketidakjelasan dan 
adanya unsur taruhan di dalamnya. Imam Nawawi mengatakan: "Larangan jual beli gharar merupakan pokok penting dari kitab jual-beli. Oleh karena itu Imam Muslim menempatkannya di depan. Permasalahan yang masuk dalam jual-beli jenis ini sangat banyak, tidak terhitung". Di lihat dari terjadi jual-beli gharar bisa ditinjau dari tiga sisi. Pertama: Jual-beli barang yang belum ada ( $m a$ 'dum), seperti jual beli habal al habalah (janin dari hewan ternak). Kedua: Jual beli barang yang tidak jelas (majhul), baik yang muthlak, seperti pernyataan seseorang: "Saya menjual barang dengan harga seratus ribu rupiah", tetapi barangnya tidak diketahui secara jelas, atau seperti ucapan seseorang: "Aku jual motor ku ini kepadamu dengan harga sepuluh juta”, namun jenis dan sifat-sifatnya tidak jelas. Atau bisa juga karena ukurannya tidak jelas, seperti ucapan seseorang: "Aku jual tanah kepadamu seharga lima puluh juta", namun ukuran tanahnya tidak diketahui. Ketiga: Jual-beli barang yang tidak mampu diserahterimakan, seperti jual beli mobil hasil dari curian.

Imam An-Nawawi menyatakan: "pada asalnya jual-beli gharar dilarang dengan dasar hadits ini”. Maksudnya adalah, yang secara jelas mengandung unsur gharar, dan mungkin dilepas darinya. Adapun hal-hal yang dibutuhkan dan tidak mungkin dipisahkan darinya, seperti fondasi rumah, membel ihewan yang mengandung dengan adanya kemungkinan yang dikandung hanya seekor atau lebih, jantan atau betina. Juga apakah lahir sempurna atau cacat. Demikian juga membeli kambing yang memiliki air susu dan sejenisnya. Menurut ijma', semua (yang demikian) ini diperbolehkan. Juga, para ulama menukilkan ijma' tentang bolehnya barang-barang yang mengandung gharar yang ringan. Di antaranya, umat ini sepakat mengesahkan jual-beli baju jubah mahsyuwah".

Dalam kitab Ibnul Qayyim menyatakan: "terkadang, sebagian gharar dapat disahkan, apabila hajat mengharuskannya. Misalnya, seperti ketidaktahuan mutu fondasi rumah dan membeli kambing hamil dan yang masih memiliki air susu'. Hal ini disebabkan, karena fondasi rumah ikut dengan rumah, dan karena hajat menuntutnya, lalu tidak mungkin melihatnya.

Maysir adalah taruhan (judi) yang terjadi pada perdagangan. Berjudi disetarakan dengan menyembah berhala (kemusyrikan) adalah termasuk dosa besar yang dilarang oleh Allah Ta'ala. Tujuan Allah Ta'ala berjudi dikategorikan sebagai dosa besar karena judi termasuk praktik yang isinya taruhan spekulasi bukan bisnis murni.

\section{Pembiayaan Pada Investasi Real Asset}

Bank syariah memberikan pembiyaan kepada usaha real asset dipengaruhi oleh tiga faktor yaitu: (1) Dilarang bank syariah melakukan praktek riba. (2) Dana di bank syariah mesti disalurkan untuk kegiatan usaha yang produktif. (3) Bank syariah dilarang melakukan pelbagai bentuk kegiatan spekulasi seperti saham dan valuta asing.

Fiman Allah Ta'ala yang berkenaan dengan pembiayaan bank syariah pada investasi real asset pada QS. Al Baqarah (2) ayat 261:

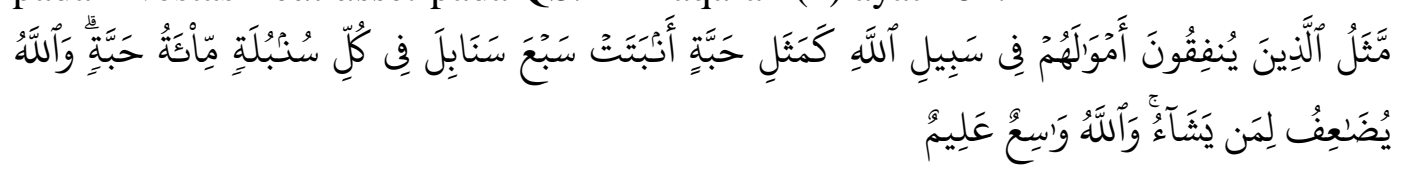

Artinya "Perumpamaan (nafkah yang dikeluarkan oleh) orang-orang yang menafkahkan hartanya di jalan Allah adalah serupa dengan sebutir benih yang 
menumbuhkan tujuh bulir, pada tiap-tiap bulir seratus biji. Allah melipatgandakan (ganjaran) bagi siapa yang dia kehendaki dan Allah Maha luas (karunia-Nya) lagi Maha Mengetahui”.

Dari surat Al Baqarah ayat 261 di atas, juga merupakan informasi tentang pentingnya investasi meskipun tidak secara kongkrit berbicara investasi terutama dalam real asset, karena yang termaktub menyampaikan tentang betapa beruntungnya orang yang menginfaqkan hartanya dijalan Allah Ta'ala. Ayat ini kalau dibaca dari perspektif ekonomi jelas akan mempengaruhi kehidupan kita didunia. Jika banyak infak terkumpul maka sebenarnya ia menolong banyak orang miskin untuk melakukan kegiatan usaha dan berproduktifitas kearah yang lebih baik.

\section{Berbagi Keuntungan Dan Resiko Rugi (Profit and Loss)}

Berbagi keuntungan dan resiko rugi (Profit and loss) sharing merupakan perjanjian atas sesuatu jenis perkongsian, dimana pihak pertama (shahibul maal) menyediakan dana dan pihak kedua (mudharib) bertanggung jawab atas pengelolaan usaha. Keuntungan hasil usaha dibagi sesuai dengan nisbah porsi bagi hasil yang telah disepakati bersama sejak awal maka kalau mengalami kerugian shahibul maal akan kehilangan sebagian imbalan dari hasil kerja keras dan managerial skill selama proyek berlangsung. Hal ini pernah Nabi Muhammad Shallallahu 'Alaihi Wasallam ketika bekerjasama dengan seorang pelaku usaha wanita bernama Siti Khadijah. Adapun caranya, Khadijah menyerahkan modal berupa barang dagangan untuk dibawa Muhammad berniaga antara negeri Makkah dengan Sham (Syiria).

Di antara sunnah Nabi yang berkaitan dengan perjanjian profit and loss sharing adalah Hadits yang diriwayatkan oleh Ibn Majah bahwa Rasulullah Shallallahu 'Alaihi Wasallam bersabda: "Tiga perkara yang mengandung berkah adalah jual beli yang ditangguhkan, melakukan muqaradah (nama laindari mudharabah), mencampurkan gandum dengan tepung untuk keperluan keluarga atau rumah tangga bukan untuk dijual".

\section{Penerapan Bank Syariah Yang Murni Syariah}

Pada dasarnya, kegiatan bank syariah di dalam Islam selalu dilandaskan pada prinsip prinsip syariah yang bersumber dari Al-Quran dan Sunnah. Seperti diharamkannya riba, dan diperbolehkannya jual beli yang tertera pada surat AlBaqarah (2) ayat 275. Berdasarkan dari sumber Al-Quran dan Sunnah tersebut, maka ada 4 tujuan dari kegiatan bank syariah berdasarkan syariah Islam adalah: (1) Menempatkan ibadah kepada Allah Ta'ala lebih dari segalanya. Tujuan utama usaha bank syariah ialah untuk mencari ridho Allah Ta'ala bukan semata-mata untuk mencari keuntungan materil. Melakukan aktivitas bank syariah diniatkan ibadah akan mendapatkan hasil yang lebih dibandingkan niat untuk mendapatkan harta. Dengan diniatkan untuk beribadah maka kita akan mendapatkan dua hal sekaligus yaitu pahala dan harta. (2) Menjadikan sarana kegiatan bank syariah untuk mencapai kesehateraan hidup diakhirat dengan mendapatkan surga. Ini karena seorang muslim meyakini bahwa akan ada kehidupan yang kekal kelak di akhirat, dan derajat yang tinggi bagi kehidupan seorang hamba di akhirat nanti ialah mereka yang mampu meningkatkan ketaatannya kepada Allah Ta'ala yang telah menciptakan dirinya. (3) Mencapai distribusi dana, konsep kegiatan bank 
syariah ialah menciptakan distribusi dana dari yang mempunyai kelebihan dana disalurkan kepada yang membutuhkan dana. Pada setiap aktivitas ekonomi antara bank dan nasabah mendapatkan laba atau keuntungan yang sama rata sehingga tidak adanya suatu diskriminasi. (4) Meraih tujuan perekonomian yang diperintahkan Allah Ta'ala. Kegiatan bank syariah adalah suatu kegiatan yang mampu memberikan dampak baik terhadap semua masyarakat. Diharapkan dengan adanya konsep keuangan syariah ini, mampu memberikan kesejateraan dan kemaslahatan bagi seluruh pelaku kegiatan usaha.

\section{KESIMPULAN}

Dalam paper ini, tujuan peneliti adalah membuat kembali konsep teori bank syariah yang sesuai dengan Al-Quran dan Hadits. Penelitian ini perlu dilakukan mengingat bahwa kegiatan operasional bank syariah, terutama di Indonesia telah banyak mendapat kritikan oleh para peneliti akedemisi karena terjadi beberapa penyimpangan kegiatan perbankan syariah yang tidak sesuai dengan ketentuan syariat Islam. Hasil penelitian menunjukkan bahwa teori bank syariah berbentuk seperti bangunan dimana fondasi dari bank syariah adalah akidah berdasarkan Al-Quran dan Hadits serta menjalankan sifat Rasulullah Shallallahu 'Alaihi Wasallam terdiri dari sidiq, fathanah, amanah dan tabliqh. Setelah fondasi sudah ada maka dapat menjalankan aturan bank syariah berdasarkan pada syariat yang terdri dari: larangan segala praktek riba, larangan pembiayaan usaha maysir dan gharar, Pembiayaan pada real asset, berbagi keuntungan dan risiko rugi (profit and loss). Apabila syariat sudah dijalankan pada perbankan syariah maka akan terwujud bank syariah yang murni syariah sehingga mendapat ridho Allah Ta'ala.

\section{DAFTAR PUSTAKA}

Ahmad, Ausaf. 1987. Development and Problems of Islamic Banks. Jeddah: Islamic Research and Training Institute, Islamic Development Bank.

Ansari, Sanaullah, and Atiqa Rehman. 2011. "Financial Performance of Islamic and Conventional Banks in Pakistan: A Comparative Study". 8th International Conference on Islamic Economics and Finance-Doha 1 (1): 1-19.

Atsari, Abu Isma'il Muslim. 2018. Akidah Dan Syariat. almanhaj.or.id. https://almanhaj.or.id/11311-akidqah-dan-syariat.html.

Babatunde, Onakoya Adegbemi, and Oladipupo A Olaitan. 2013. "The Performance of Conventional and Islamic Banks in the United Kingdom:

A Comparative Analysis". Journal of Research in Economics and International Finance 2 (2): 29-38.

Bahraen, Raehanul. 2019. Perbedaan antara Aqidah, Tauhid dan Manhaj. Muslim.or.id. https://muslim.or.id/52250-perbedaan-antara-aqidah-tauhiddan-manhaj.html.

Beck, Thorsten, Asli Demirgüç-Kunt, and Ouarda Merrouche. 2010. "Islamic vs. Conventional Banking: Business Model, Efficiency and Stability". Working Paper 5446 (WPS5446). The World Bank Development Research 
Group Finance and Private Sector Development Team. https://core.ac.uk/download/pdf/161802118.pdf.

El-Galfy, Ahmed, and Khiyar Abdalla Khiyar. 2012. "Islamic Banking And Economic Growth: A Review". Journal of Applied Business Research (JABR) 28 (5): 943-956. https://doi.org/10.19030/jabr.v28i5.7236.

Erol, Cengiz, and Radi El-Bdour. 1989. "Attitudes, Behavior and Patronage Factors of Bank Customers Towards Islamic Banks." International Journal of Bank Marketing 7 (6): 31-37. https://doi.org/10.1108/02652328910132060.

Gerrard, Philip, and J. Barton Cunningham. 1997. "Islamic Banking: A Study in Singapore" International Journal of Bank Marketing 15 (6): 204-216. https://doi.org/10.1108/02652329710184433.

Iqbal, Munawar. 2001. "Islamic and Conventional Banking in the Nineties: A Comparative Study". Islamic Economic Studies 8 (2): 1-28. https://papers.ssrn.com/sol3/papers.cfm?abstract_id=3166767.

Iqbal, Zamir, and Abbas Mirakhor. 2007. "Progress and Challenges of Islamic Banking”.Thunderbird International Business Review 41 (4-5): 56-68. https://doi.org/10.1002/tie.4270410406.

Jaffar, Muhammad, and Irfan Manarvi. 2011. "Performance Comparison of Islamic and Conventional Banks in Pakistan". Global Journal of Management and Business Research 11 (1): 59-66. https://www.journalofbusiness.org/index.php/GJMBR/article/view/454.

Kader, J.M., A.J. Asarpota, and A. Al-Maghaireh. 2007. "Comparative Financial Performance of Islamic Banks vis-à-vis Conventional Banks in the UAE". Proceeding on Annual Student Research Symposium and the Chancellor's Undergraduate Research Award. http://sra. uaeu.ac.ae/CURA.

Mannan, M. A. 1968. "Islam and Trend in Modern Banking: Theory and Practice of Interest Free Banking”. Islamic Review and Arab Affairs: 73-95.

Merchant, Imtiaz P. 2012. "Empirical Study of Islamic Banks Versus Conventional Banks of GCC". Global Journal of Management and Business $\quad$ Research $12 \quad$ (20): 33-41. http://journalofbusiness.org/index.php/GJMBR/article/view/860.

Muhith, Abdul. 2012. "Sejarah Perbankan Syariah". Attanwir: Jurnal Kajian Keislaman dan Pendidikan 1 (2): 69-84. http://ejournal.kopertais4.or.id/pantura/index.php/attanwir/article/view/310 8.

Naser, Kamal, Ahmad Jamal, and Khalid Al-Khatib. 1999. "Islamic Banking: A Study of Customer Satisfaction and Preference in Jordan." International Journal of Bank Marketing 17(3), 135-150. https://doi.org/10.1108/02652329910269275.

Kusnan, Mokhammad Ainur Rofiq, and Lukman Hakim. 2018. "Peran Ulama dalam Sosialisasi Pengembangan Perbankan Syariah". Prosiding Seminar Nasional dan Call for Papers Manajemen, Akuntansi, dan Perbankan. 1252-1266. http://conferences.uinmalang.ac.id/index.php/semnasfe/article/view/781 .

Rammal, Hussain G., and Ralf Zurbruegg. 2013. "Measuring the Awareness of Australian Muslims Towards Shariah Compliant Banking Products". 
Indonesian Management and Accounting Research 12 (1): 1-15. http://dx.doi.org/10.25105/imar.v12i1.1171.

Rosly, Saiful Azhar, and Mohd. Afandi Abu Bakar. 2003. "Performance of Islamic and Mainstream Banks in Malaysia." International Journal of Social Economics $\quad 30 \quad$ (12): https://doi.org/10.1108/03068290310500652.

Saeed, M. 1996. Islamic Banking and Interest. Netherlands: E.J. Brill.

Saiti, Buerhan. 2015. "The Awareness and Attitude towards Islamic Banking: A Study in Malaysia". Global Review of Islamic Economics and Business 2 (3): 172-196. https://doi.org/10.14421/grieb.2015.023-02.

Samad, Abdus. 1999. "Comparative Efficiency of the Islamic Bank Malaysia visà-vis Conventional Banks." International Journal of Economics, Management and Accounting 7 (1): 1-25. https://journals.iium.edu.my/enmjournal/index.php/enmj/article/view/46.

Samad, Abdus. 2004. "Performance of Interest Free Islamic Banks vis-à-vis Interest-Based Conventional Banks of Bahrain". International Journal of Economics, Management and Accounting 12 (2): 1-25. https://journals.iium.edu.my/enmjournal/index.php/enmj/article/view/99.

Samad, Abdus, and M. Kabir Hassan. 2006. "The Performance of Malaysian Islamic Bank during 1984-1997: An Exploratory Study". International Journal of Islamic Financial Services 1 (3), 1-14. https://dx.doi.org/10.2139/ssrn.3263331.

Wahidudin, Ahmad Nazri, Ulaganathan Subramanian, and Pengiran Abd. Mutalib Kamaluddin. 2012. "Determinants of Profitability- A Comparative Analysis of Islamic Banks and Conventional Banks in ASEAN countries". $2^{\text {nd }}$ International Conference on Accounting, Business and Economic (ICABEC2012), MS Garden Hotel, Kuantan Pahang; Malaysia. https://mpra.ub.uni-muenchen.de/46237.

Widagdo, Ari Kuncara, and Siti Rochmah Ika. 2008. "The Interest Prohibition and Financial Performance of Islamic Banks: Indonesia Evidence." Interational Business Research 1 (3): 98-109. https://citeseerx.ist.psu.edu/viewdoc/download?doi=10.1.1.914.1362\&rep $=$ rep1\&type $=$ pdf\#page $=99$.

Zeitun, Rami. 2012. "Determinants of Islamic and Conventional Banks Performance in GCC Countries Using Panel Data Analysis." Global Economy and Finance Journal 5 (1), 53-72. https://www.academia.edu/download/34480864/Determinants_of_Islamic_ and_conventional_banks.pdf. 